\title{
Sosialisasi Minuman Rempah Penambah Imunitas Tubuh Dalam Upaya Mencegah Terpapar Virus Corona (Covid-19)
}

\author{
Irma Zarwinda $^{1^{*}}$, Elfariyanti $^{2}$, Hardiana $^{3}$, Yuni Dewi Safrida ${ }^{4}$ \\ ${ }^{1,2,3,4}$ Akademi Analis Farmasi dan $\quad M$ akan a $n \quad B$ and a $A c e h$ \\ *Koresponden email: zarwindairma26@gmail.com
}

\begin{abstract}
ABSTRAK
Coronavirus Disease 2019 (COVID-19) adalah penyakit jenis baru yang belum pernah diidentifikasi sebelumnya pada manusia. Menjaga daya tahan tubuh atau imunitas termasuk salah satu kunci mencegah terinveksi virus tersebut diantaranya dengan cara mengkonsumsi minuman yang dibuat dari rempah-rempah seperti jahe, kunyit, sereh, kapulaga, cengkeh, kayu manis dan lainnya. Pelaksanaan PKM ini bertujuan untuk melakukan sosialisasi minuman rempah penambah imunitas tubuh dalam upaya mencegah terpapar virus covid-19. Kegiatan ini dilaksanakan di Desa Mireuk Lamreudeup Kecamatan Baitussalam Kabupaten Aceh Besar, hari Kamis Tanggal 10 Desember 2020, metode sosialisasi berupa ceramah dan diskusi. Bahan dan peralatan yang di gunakan di kegiatan ini seperti Spanduk, Brosur, minuman rempah kunyit asam dan bahan rempah yang digunakan untuk pembuatan minuman rempah. Peserta yang mengikuti kegiatan ini adalah 30 orang. Kegiatan ini berjalan dengan lancar dan mendapatkan tanggapan yang baik dari masyarakat Desa Mireuk Lamreudeup. Peserta sangat antusias dalam proses penyuluhan ini karena mendapatkan ilmu dan pengetahuan baru tentang minuman rempah yang ternyata memiliki khasiat yang luar biasa untuk tubuh. Kegiatan ini juga menjelaskan tentang menjaga pola hidup sehat di masa pandemi.
\end{abstract}

Kata kunci : Covid-19, Minuman, Rempah

\section{ABSTRACT}

Coronavirus Disease 2019 (COVID-19) is a new type of disease that has never been previously identified in humans. Maintaining immunity is one of the keys to preventing being infected with the virus, including by consuming drinks made from spices such as ginger, turmeric, lemongrass, cardamom, cloves, cinnamon and others. The implementation of this PKM aims to socialize the immune-boosting spice drink in an effort to prevent exposure to the COVID-19 virus. This activity was carried out in Mireuk Lamreudeup Village, Baitussalam District, Aceh Besar District, Thursday, December 10, 2020, the method of socialization was in the form of lectures and discussions. Materials and equipment used in this activity such as banners, brochures, sour turmeric spice drinks and spice ingredients used for making spice drinks. The participants who took part in this activity were 30 people. this activity went smoothly and received a good response from the people of Mireuk Lamreudeup Village. Participants were very enthusiastic in this counseling process because they gained new knowledge and knowledge about spice drinks which turned out to have extraordinary properties for the body. This activity also explains about maintaining a healthy lifestyle during the pandemic. 
BAKTIMAS

Jurnal Pengabdian pada Masyarakat
Vol. 3, No. 1,

Maret 2021
eISSN 2685-113x

pISSN 2685-0303

Keywords : Covid-19, Drinks, Spices

\section{PENDAHULUAN}

Corona virus adalah keluarga besar virus yang menyebabkan penyakit mulai dari gejala ringan sampai berat. Ada setidaknya dua jenis coronavirus yang diketahui menyebabkan penyakit yang dapat menimbulkan gejala berat seperti Middle East Respiratory Syndrome (MERS) dan Severe Acute Respiratory Syndrome (SARS). Coronavirus Disease 2019 (COVID-19) adalah penyakit jenis baru yang belum pernah diidentifikasi sebelumnya pada manusia. Virus penyebab COVID-19 ini dinamakan SarsCoV-2.Virus corona adalah zoonosis (ditularkan antara hewan dan manusia).Penelitian menyebutkan bahwa SARS ditransmisikan dari kucing luwak (civet cats) ke manusia dan MERS dari unta ke manusia. Adapun, hewan yang menjadi sumber penularan Covid 19 ini masih belum diketahui (Kemenkes, 2020).

Pada tanggal 30 Januari 2020 WHO telah menetapkan sebagai Kedaruratan Kesehatan Masyarakat Yang Meresahkan Dunia/ Public Health Emergency of International Concern (KKMMD/PHEIC). Penambahan jumlah kasus covid-19 berlangsung cukup cepat dan sudah terjadi penyebaran antar negara (Kemenkes, 2020). Berbagai cara diupayakan untuk mencegah terpaparnya virus corona ini, salah satunya dengan menjaga sistem imun. Penyebaran virus bergantung pada tingkat kekebalan tubuh seseorang. Apabila sistem imun menurun, seseorang akan lebih berisiko terserang virus. Berdasarkan Riset Kesehatan Dasar yang dilakukan oleh Kementerian Kesehatan pada tahun 2018 memaparkan bahwa cukup banyak masyarakat Indonesia mengalami gangguan kesehatan yang fatal ketika terinfeksi virus corona akibat dari pola makan yang tidak sehat (Humas UNS, 2020). Selain mematuhi protokol kesehatan, upaya yang dapat dilakukan untuk meningkatkan imun tubuh dan mencegah infeksi adalah mengonsumsi pangan fungsional (Nuraini dan Kuswanto, 2020).

Rempah-rempah adalah salah satu pilihan bahan aktif yang bisa dibuat menjadi pangan fungsional. Minuman fungsional merupakan minuman yang apabila dikonsumsi dapat memberikan pengaruh positif terhadap kesehatan tubuh sebab mengandung unsur-unsur zat gizi atau non zat gizi. Maka dari itu, minuman fungsional berperan dalam perlindungan atau pencegahan, pengobatan terhadap penyakit, peningkatan kinerja fungsi tubuh optimal, serta meningkatkan daya imunitas tubuh (Pratiwi, 2014). Minuman fungsional dapat dijadikan sebagai sumber antioksidan sebab pada tanaman bahan yang digunakan mengandung senyawa metabolit sekunder seperti flavonoid, tanin, fenolik, dan antosianin (Sari, 2016). Minuman tradisional Indonesia berupa minuman jahe, minuman kunyit asam, minuman temulawak, dan minuman beras kencur dapat berfungsi sebagai antioksidan (Septiana dkk, 2017).

Indonesia merupakan negara yang memilki potensi rempah-rempah yang melipah, seperti jahe yang mengandung potensi antimikroba yang dapat membantu dalam mengobati penyakit menular dan baik dikonsumsi ketika demam untuk menghangatkan badan sekaligus meningkatkan daya tahan tubuh, kunyit yang mengandung kurkumin yang dapat meningkatkan daya tahan tubuh dan mengobati radang, Sereh yang baik untuk memelihara daya tahan tubuh, antioksidan dan meredakan flu. Selanjutnya kapulaga yang kaya akan fitonutrien sebagai antioksidan yang dapat menangkal radikal bebas. Cengkeh dapat digunakan untuk mengobati masalah pernafasan, mengatur suhu tubuh dan flu. Terakhir kayu manis yang dipercaya 
Irma Zarwinda, dkk.

dapat merangsang sirkulasi darah sehingga badan terasa lebih hangat (Margareth, 2019). Rimpang jahe (Zingiber officinale Rosc.) memiliki kandungan senyawa aktif dari kelompok flavonoid dan polifenol yang diketahui memiliki aktivitas antiinflamasi dan antioksidan yang tinggi (Batubara dan Prastya, 2020). Kencur ( Kaempferia galanga L.) merupakan salah satu komponen yang sangat terkenal selain sebagai obat tradisional kencur juga bisa bermanfaat pada industri kosmetik, penyedap makanan dan minuman serta rempah. Apabila dipadu dengan saripati beras akan menjadi minuman penyegar, orang Jawa biasa menyebutnya dengan sebutan beras kencur ( Handayani, 2013),

Munculnya pandemi Covid-19 menjadikan beberapa jenis rempah terutama yang mengandung kurkumin semakin diminati masyarakat. Kunyit merupakan tanaman obat dengan kandungan bahan aktif utama kurkumin sebesar 3- 5\% (Kementerian Pertanian, 2020). Rimpang kunyit (Curcuma domestica Val.) memiliki kandungan senyawa kurkumin yang memiliki manfaat antivirus, antinosiseptif, anti-inflamasi, antipiretik, dan antifatigue yang efektif untuk menangani gejala pasien yang terinfeksi COVID-19. Bukti ilmiah menunjukkan bahwa kurkumin memiliki peran potensial untuk mengobati COVID-19 (Babaei et al., 2020).

\section{METODE PELAKSANAAN KEGIATAN}

Metode yang digunakan dalam kegiatan ini adalah metode sosialisasi. Adapun tahap awal dari pelaksanaan kegiatan ini ialah dengan mencari dan menentukan tempat untuk penyuluhan yaitu bertempat di Desa Mireuk Lamreudeup di kecamatan Baitussalam, Kabupaten Aceh Besar. Selanjutnya mengurus surat keterangan izin pelaksanaan kegiatan penyuluhan yang dikeluarkan oleh pihak kampus AKAFARMA ke pihak desa (gampong), dilanjutkan dengan permintaan perizinan beserta penetapan tanggal dan hari yang tepat dengan masyarakat gampong. Setelah semua perjanjian lengkap, selanjutnya yaitu mempersiapkan segala kebutuhan acara di mulai dari pencetakan brosur, spanduk, persiapan bahan presentasi, persiapan minuman herbal rempah yang akan dibagikan. Kegiatan dilaksanakan pada hari Kamis Tanggal 10 Desember 2020 pada pukul 10.00 s.d. 11.15 WIB.

Bahan dan peralatan yang di gunakan di kegiatan ini seperti Spanduk, Browsur, Infokus, dan bahan rempah yang digunakan untuk pembuatan minuman herbal rempah. Peserta yang mengikuti kegiatan ini antara lain adalah " Masyarakat Desa Mireuk Lamreudeup " yang beranggotakan 30 orang.

Adapun susunan acara pada kegiatan penyuluhan Pengabdian Msyarakat dengan tema "Minuman Rempah Dalam Meningkatkan Daya Tahan Tubuh dan Pencegahan Covid-19" dapat dilihat pada Tabel 1.

Tabel 1 Susunan Acara PKM

\begin{tabular}{lllll}
\hline No & Jam (WIB) & Tanggal & Hari & Acara \\
\hline 1. & $10.30-10.10$ & 10 Desember 2020 & Kamis & Pembukaan \\
\hline 2. & $10.10-10.20$ & 10 Desember 2020 & Kamis & Perkenalan \\
\hline 3. & $10.20-10.50$ & 10 Desember 2020 & Kamis & Materi dan pembagian Brosur \\
\hline 4. & $10.50-11.00$ & 10 Desember 2020 & Kamis & Tanya Jawab \\
\hline 5. & $11.00-11.05$ & 10 Desember 2020 & Kamis & $\begin{array}{l}\text { Pembagian Snack dan } \\
\text { minuman rempah }\end{array}$ \\
\hline
\end{tabular}




\begin{tabular}{lllll}
\hline 6. & $11.05-11.10$ & 10 Desember 2020 & Kamis & Penutup \\
\hline 7. & $11.10-11.15$ & 10 Desember 2020 & Kamis & Foto bersama \\
\hline
\end{tabular}

\section{HASIL DAN PEMBAHASAN}

Covid 19 merupakan penyakit yang disebabkan oleh virus corona. Virus ini menyerang saluran pernafasan. Gejala Covid-19 yang paling umum adalah demam, kelelahan, dan batuk kering. Beberapa orang mungkin mengalami sakit dan nyeri, hidung tersumbat, pilek, sakit tenggorokan atau diare. Proses penularan terjadi dari orang ke orang sehingga perlu adanya pencegahan yang harus dilakukan. Adapun cara penanggulangan dan pencegahan yang benar yaitu dengan selalu menjaga gaya hidup sehat (makan, tidur, olahraga) untuk imunitas tubuh, rajin mencuci tangan, menjaga etika batuk dan bersin, menghindari kerumunan, menghindari menyentuh mata, mulut dan hidung, mengurangi interaksi dengan orang lain, dan lain sebagainya. Sebagai bentuk partisipasi yang dapat dilakukan yaitu dengan mendukung kebijakan pemerintah mengenai sekolah di rumah, bekerja dari rumah dan ibadah di rumah. Serta selalu melakukan hal-hal positif yang mampu mengurangi rasa khawatir terhadap maraknya virus corona (Kemenkes, 2020). Adapun aktivitas peserta saat Kegiatan penyuluhan berlangsung dapat dilihat pada Tabel 2.

Tabel 2. Aktivitas peserta dalam kegiatan PKM

\begin{tabular}{llc}
\hline No & Interaksi yang diamati & Persen $(\%)$ \\
\hline 1 & Mendengarkan penjelasan pemateri & 100 \\
\hline 2 & Menerima brosur materi dan membacanya & 90 \\
\hline 3 & $\begin{array}{l}\text { Terlibat bertanya dan menjawab soal dari pemateri dan } \\
\text { rekan }\end{array}$ & 85 \\
\hline 4 & Menerima minuman rempah dan melakukan testimoni & 95 \\
\hline
\end{tabular}

Berdasarkan Tabel 2. dapat dilihat bahwa aktivitas peserta yaitu masyarakat saat pengabdian berlangsung, dimana keempat komponen tersebut yaitu yang pertama mendengarkan penjelasan pemateri mendapatkan persen $100 \%$, menerima brosur materi dan membacanya sebesar $90 \%$, terlibat bertanya dan menjawab soal dari pemateri dan rekan sebanyak $85 \%$, dan yang terakhir menerima minuman rempah dan melakukan testimoni sebanyak $95 \%$. Dari persentasi yang didapat kegitan ini dapat dikatakan berjalan dengan lancar. Penjelasan tentang minuman rempah dapat dilihat pada Gambar 1. 
Irma Zarwinda, dkk.

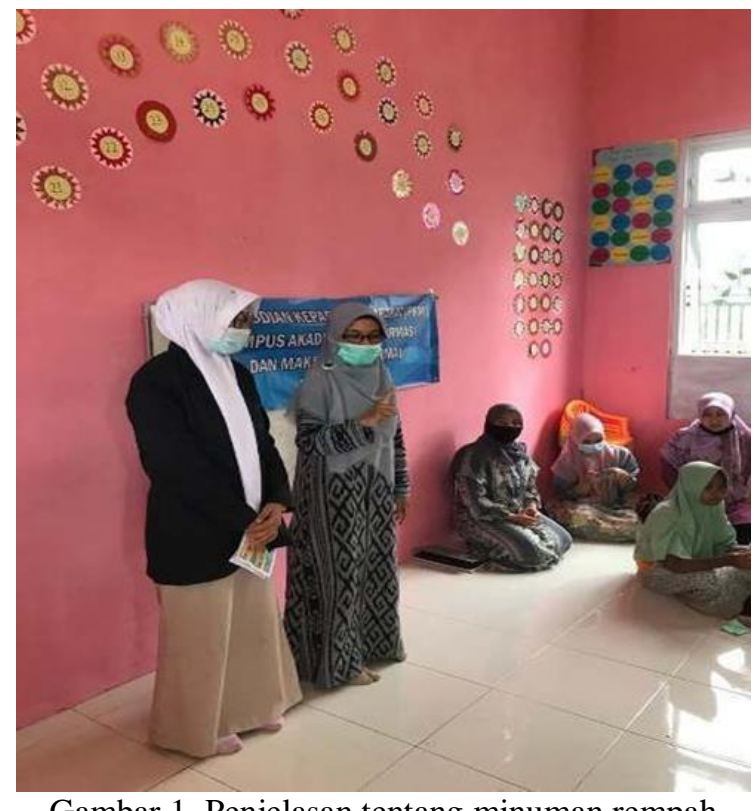

Gambar 1. Penjelasan tentang minuman rempah

Salah satu upaya dari setiap individu untuk memutuskan rantai penularan Covid-19 adalah kesadaran menjaga kesehatan dirinya sendiri dengan mengonsumsi makanan dan minuman yang tidak hanya memenuhi kebutuhan zat-zat esensial pada tubuh, tetapi juga memberikan manfaat lebih seperti perlindungan untuk tubuh dengan meningkatkan stamina dan imunitas dan bahkan dapat memberikan efek perlindungan terhadap beberapa gangguan penyakit. Makanan dan minuman tersebut disebut sebagai Pangan Fungsional (Sanger, dkk., 2018). Adapun pangan fungsional pada kegiatan pengabdian ini merupakan minuman rempah yang sering digunakan oleh ibuibu sebagai bumbu pada masakan.

Sebelum dilakukan pengabdian masyarakat tentang minuman rempah dalam upaya untuk mencegah covid-19, untuk memudahkan proses pengabdian dan prosesnya berjalan lancar didesainter lebih dahulu brosur tentang minuman rempah yang dapat dilihat pada Gambar 2. 


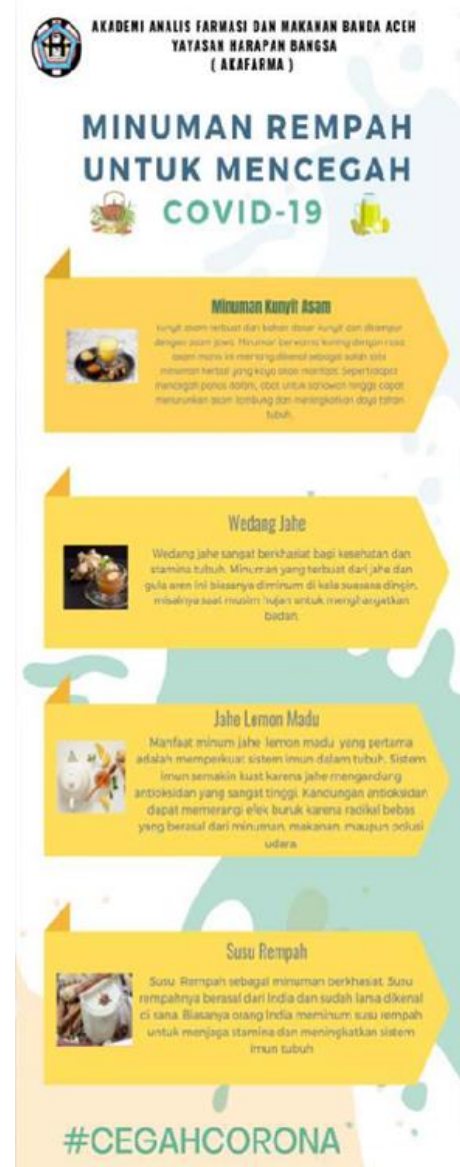

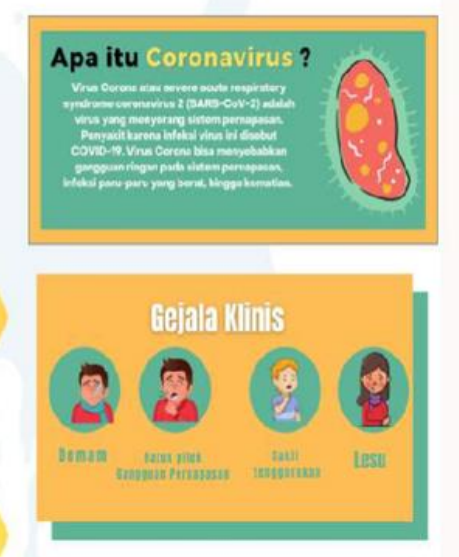

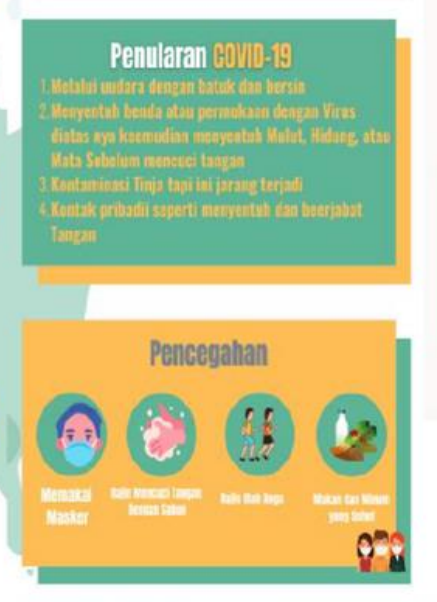

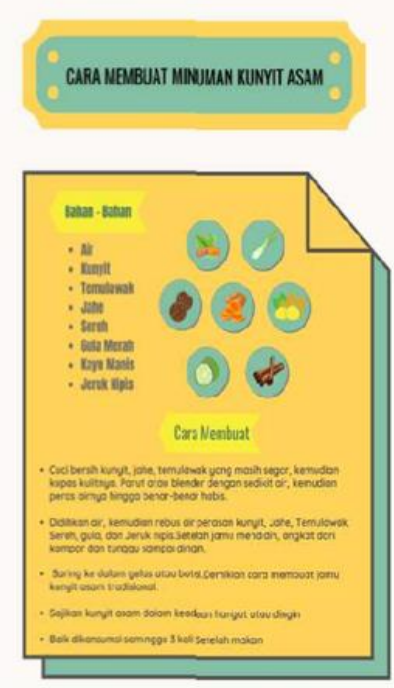

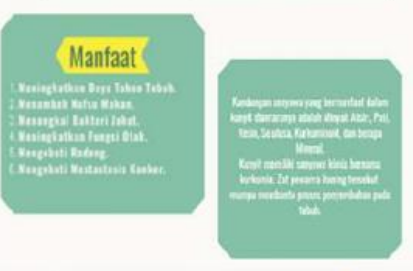

STOP PENYEBARAN COVID-19

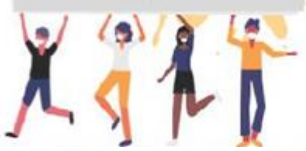

Gambar 2. Brosur minuman rempah untuk mencegah Covid-19.

Masyarakat Gampong Mireuk Lamreudeup menyambut dengan sangat antusias dan positif terhadap kegiatan yang telah di laksanakan. Hal ini di tandai dengan besarnya keingintahuan masyarakat tentang pentingnya minuman rempah bagi tubuh.Tentu saja hal ini menambah pengetahuan tentang manfaat tanaman rempah sehingga masyarakat mampu mengolah tanaman rempah untuk dijadikan minuman guna meningkatkan daya tahan tubuh dan bisa menjaga kesehatan di masa pandemi Covid 19. Selain mendapatkan penjelasan langsung tentang minuman rempah, juga dilakukan pembagian brosur minuman rempah dan khasiatnya kepada masyarakat untuk lebih memahami materi yang disampaikan, prosesnya dapat dilihat pada Gambar 3.

Penyuluhan tentang bahaya penurunan daya tahan tubuh saat Covid 19, memberikan informasi kepada masyarakat bahwa menjaga daya tahan tubuh di masa pandemi ini sangat penting dengan mengajak masyarakat untuk mengolah rempahrempah sebagai minuman yang berkhasiat, tidak hanya itu untuk menjalankan pola hidup sehat juga dengan olah raga dan istirahat yang cukup. Selain itu, kegiatan ini juga memberikan informasi tetang apa saja manfaat yang terkandung di dalam minuman rempah berkhasiat contohnya seperti minuman Kunyit, Jahe, Asam dan rempah lainnya sehingga membuat para peserta mengerti dengan manfaat yang terkandung di dalam tanaman herbal rempah tersebut. 
Irma Zarwinda, dkk.

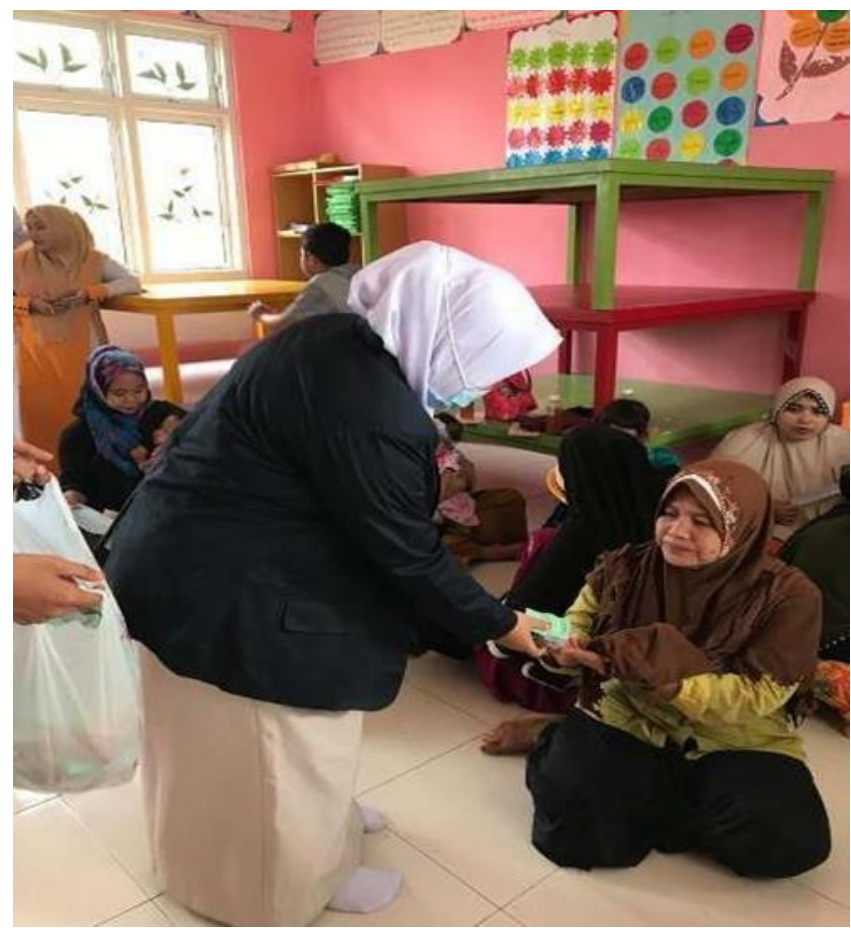

Gambar 3. Pembagian brosur dan minuman rempah kepada peserta

Agenda lain yang dilakukan pada kegiatan ini juga adalah memberikan informasi tentang beberapa hal yang harus dilakukan selama pandemi Covid 19 di dalam dan diluar rumah serta mengingatkan tentang penerapan pelaksanaan protokol kesehatan yang telah ditetapkan pemerintah.

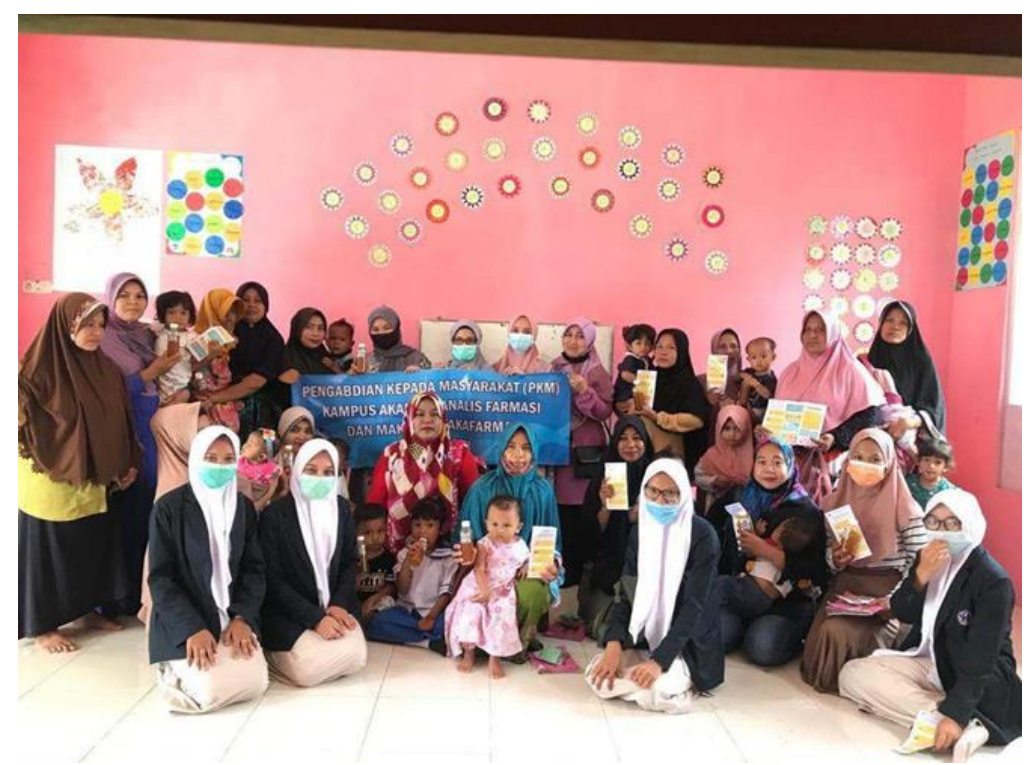

Gambar 4. Foto bersama peserta PKM 


\section{PENUTUP}

Berdasarkan kegiatan penyuluhan yang telah dilakukan, dapat disimpulkan bahwa kegiatan ini berjalan dengan lancar dan mendapatkan tanggapan yang baik dari Masyarakat Desa Mireuk Lamreudeup.Peserta sangat antusias dalam proses penyuluhan ini karena mendapatkan ilmu dan pengetahuan baru tentang minuman rempah yang ternyata memiliki khasiat yang luar biasa untuk tubuh. Kegiatan ini juga menjelaskan tentang menjaga pola hidup di masa Pandemi Covid-19.

\section{DAFTAR PUSTAKA}

Babaei, F., Nassiri-Asl, M. and Hosseinzadeh, H. 2020. Curcumin (a constituent of turmeric): New treatment option against COVID-19. Food Science and Nutrition, 8 (10): 5215-5227.

Handayani, Tuti, 2013. Apotik Hidup. Penerbit Padi ISBN:978-602- 14001-0-4

Humas UNS. 2020. Pola Makan Sehat dan Bergizi untuk Meningkatkan Imunitas saat Terserang Covid-19. https://uns.ac.id/id/uns-opinion/pola- makan-sehat-danbergizi-untuk- meningkatkan-imunitas-saatterserang-covid-19.html.

Kementerian Kesehatan RI. 2020.Pedoman Pencegahan dan Pengendalian Covid-19. Diakses di https: // covid19.kemkes.go.id/ protokol-covid-19/ kmk-no-hk=01-07menkes -413 -2020 -ttg-pedoman-pencegahan-dan-pengendalian-covid-19 pada Tanggal 10 Desember 2020.

Kementerian Pertanian, 2020. Buku Saku Bahan Pangan Potensial untuk Anti Virus dan Imun Booster. 1 ed. Jakarta: Balai Besar Penelitian dan Pengembangan Pascapanen Pertanian.

Margareth, R. 2019. Kunyit dan empat Rempah Redakan Flu Saat Musim Hujan. Di akses di https://www.tagar.id/kunyit-dan-empat-rempah-redakan-flu-saat-musim-hujan pada Tanggal 10 Desember 2020

Nuraini, V. and Kuswanto, K.R. 2020. Pencegahan dan Pengendalian Penyakit. Jurnal Masyarakat Mandiri, 4 (5): 922-929.

Sanger, G., Kaseger, B.E., Rarung, L.K., et al. 2018. Potensi beberapa Jenis Rumput Laut sebagai Bahan Pangan Fungsional, Sumber Pigmen dan Antioksidan Alami. Jurnal Pengolahan Hasil Perikanan Indonesia, 21 (2): 208.

Sari, A. N. 2016. Berbagai Tanaman Rempah sebagai Sumber Antioksidan Alami. Journal of Islamic Science and Technology, 2(2), 203-212.

Septiana, A. T., Samsi, M., dan Mustaufik, M. 2017. Pengaruh Penambahan Rempah dan Bentuk Minuman Antioksidant Berbagai Minuman Tradisional Indosensia. Jurnal AGRITECH, 37 (1) : 7-14.

Thompson, A.K. and Moughan, P.J. 2008. Innovation In The Foods Industry: Functional Foods. Innovation: Management, Policy and Practice, 10 (1): 6173. 